ELORE (ISSN 1456-3010), vol. $14-2 / 2007$.

Julkaisija: Suomen Kansantietouden Tutkijain Seura ry.

[http://www.elore.fi/arkisto/2_07/vir2_07.pdf]

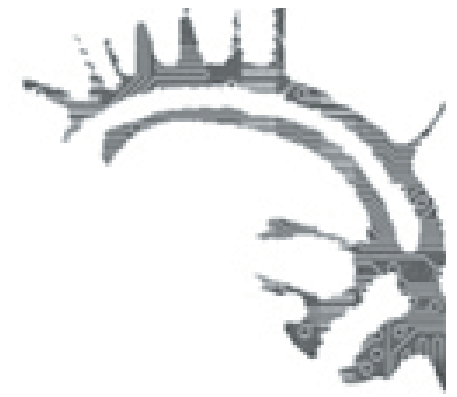

\title{
Karjanhoitajat Mekassa: MbOrorojen PYHIINVAELLUKSEN MORAALITALOUS
}

\section{$\underline{\text { Tea Virtanen }}$}

Kaikkialla maailmassa ihmisten pyhiinvaelluskertomuksissa universaalit ja paikalliset elementit lomittuvat toisiinsa. Silloin kun Kamerunin Adamaoualla asuvat, karjanhoitoa harjoittavat mbororo-fulbet - lyhyemmältä nimeltään mbororot - puhuvat pyhiinvaelluksestaan Mekkaan, he kertovat kokemuksesta, jonka he jakavat miljoonien muiden muslimien kanssa. Siksi myös mbororojen Mekka-kerronnasta voidaan löytää yhtymäkohtia muiden muslimien pyhiinvaelluskertomuksiin. 'Tällaisia toistuvia teemoja ovat esimerkiksi jumalallinen kutsu lähteä pyhiinvaellukselle, kuvaukset pyhiinvaelluspaikoilta sekä kertominen eri pyhiinvaelluskohteilla käymisestä kronologisessa järjestyksessä.

Toisaalta mbororo-karjanhoitajien kertomaa värittää heidän oma arkinen kokemusmaailmansa, eli he tulkitsevat Mekassa näkemäänsä ja kokemaansa omasta kulttuurisesta ja sosiaalisesta viitekehyksestään käsin. Väheksymättä kaikkeen Mekkakerrontaan sisältyviä universaaleja aineksia keskityn tässä artikkelissa elementteihin, jotka tekevät näistä pyhiinvaelluskertomuksista juuri mbororojen kertomuksia. (1) Tarkastelen sellaisia mbororojen pyhiinvaellusmatkalleen antamia merkityksiä, joita ei voi ymmärtää ottamatta huomioon mbororojen omia kulttuurisia käsityksiä sekä sitä sosiaalista todellisuutta, jossa he nykyään elävät Kamerunin Adamaoualla. Analyysissani pohdin erityisesti sitä, mikä yhteys mbororojen karjalla on heidän pyhiinvaellukseensa.

Mbororot kuuluvat Länsi-Afrikan fulbeihin, joita nomadiseen karjanhoitoon liittyvän historian lisäksi yhdistää fulfulden kieli. Tämän päivän Kamerunissa elävät fulbet voidaan karkeasti jakaa kahteen ryhmään. Sosiaalisesti ja poliittisesti marginalisoituneet mbororo-fulbet harjoittavat puolipaimentolaista karjanhoitoa, kun taas aiemmin vaellushistoriansa aikana karjanhoidosta luopuneet ja muun paikallisen muslimiväestön kanssa avioliittojen kautta sekoittuneet kylä-fulbet harjoittavat nykyään erilaisia urbaaneja toimeentulomuotoja muodostaen samalla Pohjois-Kamerunissa ja Adamaouan alueella traditionaalista poliittista valtaa pitävän ryhmän. 


\section{Karjanhoitajat MeKassa}

Artikkelini perustuu kenttätyöhön, jota tein väitöskirjaani varten mbororojen parissa Kamerunin Adamaoualla, Djeremin piirikunnassa. (2) Pyhiinvaellus ei ollut itse valitsemani teema, vaan se hiipi muistiinpanoihini mbororojen oman puheen myötä. Mekassa käynti oli heille jotain, mistä minulle haluttiin spontaanisti kertoa ilman, että olisin itse nostanut asian esille. Aluksi kirjoitinkin ylös mbororojen arkipuheisiin sisältyneitä lausahduksia pyhiinvaelluksesta ja sitä sivuavista aiheista. Lopulta nauhoitin viisi vapaamuotoista teemahaastattelua, joissa sekä Mekassa käyneet että siellä käymättömät mbororot puhuvat pyhiinvaelluksesta. Haastateltaviini kuului viisi miestä ja kaksi naista, joista kaikista käytän peitenimiä.

Termi pybiinvaelluskertomus määrittyy artikkelissani laveasti: se kattaa kaiken Adamaoualla tallentamani Mekka-kerronnan. Tähän päädyin siksi, että nauhoittamani ja muistiinkirjoittamani mbororojen pyhiinvaellukseen liittyvä kerronta ei noudata tarkkaa temaattisesti kronologista kaavaa. Kenttätyöni aikana en myöskään strukturoinut haastatteluja; minulla ei ollut etukäteen valmiiksi muotoiltuja kysymyslistoja. Haastatteluissa mbororojen puhe polveileekin teemasta toiseen välillä spontaanisti, välillä aiempien keskustelujen pohjalta muotoutuneiden, itse esittämieni kysymysten siivittämänä. Etenkin useamman informantin samanaikaiset haastattelut ilmentävät pyhiinvaelluskertomusten luonnetta keskusteluna ja tuotettuna kerrontana.

\section{NÄKÖKULMIA PYHIINVAELLUKSEEN}

Pyhiinvaelluksesta käytävässä teoreettisessa keskustelussa on jo jonkin aikaa korostettu toisaalta pyhiinvaellukseksi ymmärrettyjen ilmiöiden moninaisuutta, toisaalta niiden teoreettisten näkökulmien monilukuisuutta, joiden kautta pyhiinvaellusta on mahdollista tarkastella. Tutkijoiden kirjoituksissa tämä universaaleja yleistyksiä kaihtava painotus on ottanut vauhtia Victor Turnerin pyhiinvaellusteorioihin kohdistuneesta kritiikistä. Arvostelua on saanut osakseen etenkin Turnerin essee Pilgrimages as Social Processes (1974), jossa hän soveltaa Arnold van Gennepin (1960) klassista siirtymäriittiteoriaa pyhiinvaellukseen. Gennepin ajatusten inspiroimana Turner myös korostaa itse pyhiinvaelluskohteessa vallitsevaa liminaalista communitas-tilaa, jolle ominaista on pyhiinvaeltajien statuksettomuus sekä heidän välisensä vahva yhteenkuuluvuuden tunne. (Turner 1974, 166-169, 182, 195-196.)

Pyhiinvaelluksen ja siirtymäriittien välisestä vastaavuudesta Alan Morinis $(1992,8)$ toteaa, että vaikka joistakin pyhiinvaelluksista on löydettävissä siirtymäriiteille ominainen initiaatioluonne, kaik kia pyhiinvaelluksia ei voida luokitella siirtymäriiteiksi. Toisinaan pyhiinvaellus voi olla päämäärältään lähempänä vaikkapa vahvistusriittiä. Morinis viittaa lisäksi moniin tutkimuksiin, joissa pyhiinvaellus on osoittautunut, Turnerin korostaman yhteisöllisyyden sijaan, hyvin individualistiseksi toiminnaksi. Tällöin sen tarkoituksena on esimerkiksi yksilön suora yhteys jumaluuden kanssa. (3)

Communitas-aspektin universaaliuden on kyseenalaistanut myös Michael Sallnow (1981). Andeilla tapahtuvaa pyhiinvaellusta käsittelevässä artikkelissaan hän tuo esiin joukon taloudellisia ja etnisiä juopia, jotka erottavat paikallisia pyhiinvaeltajia 


\section{TEA ViRTANEN}

toisistaan, ja toteaa, että pyhiinvaelluskohteissa mahdollisesti syntyvät uudet sosiaaliset ryhmittymät vain syventävät niitä. William Roffin $(1985,86)$ mukaan pyhiinvaelluksen liminaalitilan korostaminen Turnerin tapaan jättää huomiotta postliminaalin - eli kaiken sen, mitä tapahtuu pyhiinvaelluksen jälkeen. Christian Bawa Yamba (1990, 9-10) onkin esittänyt, että communitas-malli soveltuu parhaiten sellaisiin satunnaisiin ja väliaikaisiin pyhiinvaeltajaryhmittymiin, jotka muodostuvat pyhiinvaellusmatkan aikana ja hajoavat usein sen päätyttyä. Morinis $(1992,3-4,7)$ on edelleen kiinnittänyt huomiota antropologien taipumukseen keskittyä pyhiinvaelluksen rituaaliseen etenemiseen pyhissä paikoissa, Turnerin $(1974,210)$ sanoin "sakraaliin topografiaan". Tällöin pyhiinvaellus kokonaisprosessina sosiokulttuurisine, poliittisine ja taloudellisine kytkentöineen on jäänyt vähemmälle huomiolle.

Olen aiemmin (Virtanen 2003, 136-142) tarkastellut mbororojen pyhiinvaellusprosessia Adamaoualta Saudi-Arabian pyhiinvaelluskohteisiin ja takaisin liikkumisen näkökulmasta ja verrannut mbororojen pyhiinvaelluskertomuksia heidän muuttokertomuksiinsa. Tässä artikkelissa keskityn pyhiinvaelluksen kronologisen etenemisen sijasta Moriniksen (1992) peräänkuuluttamaan pyhiinvaelluksen kontekstualisointiin: pohdin ensin sen merkitystä mbororoille Adamaouan paikallisen hierarkian näkökulmasta, jonka jälkeen siirryn tarkastelemaan mbororojen taloudellisen ja symbolisen varallisuuden - eli karjan - ja pyhiinvaelluksen välisiä kytköksiä. Analyysin edetessä täsmentyy myös artikkelissa käyttämäni näkökulman suhde erilaisiin pyhiinvaellusteorioihin.

\section{MeKka, Jotain AIVAN MUUTA...}

Kun mbororot puhuvat bijjustaan (4) eli pyhiinvaelluksestaan Mekkaan, heidän kertomuksissaan toistuvat usein sellaiset lausahdukset kuten "se, joka ei ole käynyt Mekassa, ei tiedä, mitä onni on" tai "on tämä maailma ja on Mekka" (esim. H4; KPM1; KPM2). Tällaisiin sanontoihin kiteytyvä kahden paikan tai kahden maailman vastakohtaistaminen on tyypillistä kaikenlaisille Mekka-puheille. Saman polarisaation löysi myös Turner (1974, 167-168) lukemistaan pyhiinvaelluskertomuksista, joissa hänen mukaansa painottui paikallisen, suhteellisen muuttumattoman ja strukturoidun sosiaalisen elämän ja totaalisen pyhiinvaellusprosessin välinen vastakohta. Kun mbororot kertovat Mekasta, he asettavat tämän muslimien pyhän kaupungin vastakkain oman, karjanhoidon täyttämän jokapäiväisen elämänsä ja sen raskauden kanssa. Heidän kuvauksissaan Mekka näyttäytyy paikkana, jossa ei ole likaa, nälkää tai kärsimystä missään muussakaan muodossa. Se on paikka, jossa ihmisten ainoa työ on rukoilla Jumalaa. Moriniksen (1992, 25-26) ajatusta lainaten Mekka edustaa mbororoille täydellisyyden ideaalia vastakohtana tuttujen, jokapäiväisten elinolosuhteiden epätäydellisyydelle.

Mekan ja leirielämän vertailu voi saada myös hyvin konkreettisia muotoja. Niin tapahtui, kun karjanhoitajanainen nimeltään Hajja Rekia kertoi minulle 1990-luvun puoliväliin ajoittuneesta pyhiinvaelluksestaan. Istuessamme Rekian majan edessä tämä muisteli valtavaa lentokonetta, joka kuljetti ihmisiä Doualasta, Kamerunin suu- 


\section{Karjanhoitajat MeKassa}

rimmasta kaupungista, Jeddaan Saudi-Arabiaan. Rekia antoi katseensa vaeltaa leirin toisessa reunassa sijaitsevaan majaan ja takaisin läheiseen puuhun ja huudahti: "Se lentokone oli yhtä pitkä kuin matka tästä Saidatun majalle. Ja se oli suuri! Yhtä suuri kuin tuo puu!" (H2.)

Samankaltaisia huomioita tehdään toki ympäri muslimimaailmaa, ja niitä ovat antropologit aiemminkin dokumentoineet (ks. esim. Ferme 1994). Hajja Rekian kokeman ihmetyksen modernin kuljetusteknologian ja Mekan urbaanin vaurauden edessä jakavat tuhannet pyhiinvaeltajat, etenkin sellaiset, joiden jokapäiväisen kokemusmaailman moderni teknologia kokonaan ylittää. Rekian kokemuksesta tekee erityisesti mbororoille yhteisen kuitenkin se, että heidän tekemälleen vastakkainasettelulle oman leirinsä ja Mekan välillä löytyy vertailukohta heidän nykyiseltä asuinseudultaan Adamaoualta. Tällä viittaan leirielämän ja kyläelämän vastakohtaan, jolle karjanhoitajien ja kyläläisten (5) välinen paikallinen hierarkia pitkälti rakentuu. Kyläläisten näkökulmasta katsottuna kylä on keskus, kun taas karjanhoitajien leirit sisäänsä sulkeva savanni edustaa tilallista ja kulttuurista periferiaa, josta karjanhoitajat ilmestyvät aamuisin ja jonne he katoavat auringon laskiessa. Samalla tavalla karjanhoitajat on sijoitettu poliittisen ja kulttuurisen hierarkian pohjalle edustamaan sivistymätöntä ihmisryhmää, jonka salainen "puskaelämä" antaa kyläläisille hyvän syyn epäillä näiden islamilaisen vakaumuksen aitoutta. "Ils ne sont pas civilisés" (suom. "he eivät ole sivistyneitä") tai "ils sont sauvages" (suom. "he ovat villejä"), kuten kyläläisten usein mbororoista käyttämä ilmaisu kuuluu.

Kun pohditaan hijjun merkitystä tässä paikallisessa valta-asetelmassa, julkisen pyhiinvaelluksen voidaan ymmärtää tuovan mbororoille näkyvämmän muslimistatuksen ja hämärtävän siten paikallisia hierarkioita. Barbara Metcalf $(1990,100)$ on luonnehtinut Mekkaan suuntautuvaa pyhiinvaellusta toimintana tai performanssina, jonka arvo ei ole kyseenalaistettavissa. Mbororot, jotka kenttätyöni aikaan muodostivat huomattavan osan Adamaouan muslimipyhiinvaeltajista, voivat epäilemättä hijjullaan kuitata ainakin osittain kyläläisten ilkeämieliset vihjailut heidän salamyhkäisestä leirielämästään. Lähtiessään Mekkaan karjanhoitajat ikään kuin ylittävät paikallisen valta-asetelman ja siirtyvät kylän periferiasta oman pyhiinvaelluksensa aktiivisiksi suorittajiksi tai toimijoiksi. Voidaankin ajatella, että Mekassa paikallinen kylän ja puskan välinen dikotomia ylittyy samalla tavalla kuin Mekka ylittää kaikkien paikallisten maailmojen keskukset. Onkin ironista, että ainoat keskustelut, joissa olen kuullut kyläläisten kutsuvan itseään ja mbororoja "samaksi tai yhdeksi kansaksi" ovat koskeneet nimenomaan pyhiinvaellusta.

Vastoin pyhiinvaelluksen ja siirtymäriitin yhteismitallisuutta kohtaan esitettyä kritiikkiä (ks. esim. Gothóni 1993; Kilpeläinen 2000; Yamba 1990) voidaan pyhiinvaellus mbororojen, kuten monien muidenkin muslimien, kohdalla hyvin ymmärtää sosiaalisen statuksen nostoksi. Tätä ilmentävät erilaiset ulkoiset symbolit, kuten Mekasta palaavalle pyhiinvaeltajalle myönnettävä Alhajin tai Hajjan arvonimi (ks. myös Morinis 1992; Roff 1985). Pyhiinvaelluksen vaikutus suorittajansa statukseen onkin ollut keskeinen argumentti niissä harvoissa kommenteissa, joita Länsi-Afrikan mbororo-fulbejen pyhiinvaelluksesta on esitetty (Frantz 1978; Hickey ym. 1979). Väite pätee myös tässä artikkelissa tarkastelun kohteena oleviin mbororo-karjanhoitajiin, joille 


\section{TEA ViRTANEN}

pyhiinvaellus muodostaa merkittävän mahdollisuuden julkisen arvostuksen hankkimiseen Adamaouan monietnisessä muslimiyhteisössä. Antropologiseksi perusteluksi tämä ei kuitenkaan riitä, sillä pyhiinvaelluksen merkityksen rajoittaminen pelkäksi statuksen metsästykseksi jättäisi matkan taustalla olevat syvemmät kulttuuriset motivaatiot huomiotta. Puhuttaessa Adamaouan mbororojen pyhiinvaelluksesta tällaisena motivoijana voidaan nähdä karja, jonka jättäminen analyysin ulkopuolelle rajaisi ulos myös mbororoille erityisen tavan ymmärtää pyhiinvaellustaan. Siirryn seuraavaksi tarkastelemaan karjan yhteyttä pyhiinvaellukseen pohtimalla sellaisia karjaan liittyviä käsityksiä, jotka strukturoivat mbororojen pyhiinvaelluskokemusta. Tarkastelussani tulen nostamaan esiin fulfuldenkielisiä termejä ja kielikuvia, joiden kautta mbororot linkittävät pyhiinvaelluskokemuksen arkikokemuksiinsa ja tekevät pyhiinvaelluksesta merkityksellisen osan omaa sosiaalis-moraalista maailmaansa.

\section{Pyhinnvaellus yhteisöllisenä PROJEKTINA}

Adamaoualla kaikki tietävät, että vain niillä mbororoilla, joilla on tarpeeksi karjaa, on varaa matkata Mekkaan. Pyhiinvaellukselle lähtevät karjanhoitajat ovatkin tavallisesti henkilöitä, joilla on jo kunnioitettu asema omassa yhteisössään ja jotka nauttivat jonkinasteista arvostusta myös tämän yhteisön ulkopuolella. Ulkopuolelta tulevaan arvostukseen liittyy kuitenkin tietynlainen, aiemmin kuvaamaani kylän ja puskan väliseen hierarkkiseen vastakkainasetteluun sisältyvä ambivalenssi. Huolimatta siitä, että isoa karjamäärää arvostetaan varallisuuden muotona - onhan myös monella kyläläisellä karjaa - ajatus mbororoista ihmisinä, jotka touhuavat nautojensa kanssa päivät pitkät savannilla, leimaa heidät helposti itsepäisiksi ja tietämättömiksi olennoiksi - "Ils sont comme leur bœufs" (suom. "he ovat kuin nautansa"), kuten paikallinen, mbororoja pilkkaava sanonta kuuluu. Pyhiinvaelluksen yhteydessä karjanhoitajien karja saa kuitenkin aivan uuden ulottuvuuden: Karjasta tulee väline sekä henkisesti että materiaalisesti arvostetulle päämäärälle. Myymällä karjaa karjanhoitaja saa rahaa maksaakseen matkansa Mekkaan ja täyttääkseen siten uskonnollisen velvollisuutensa.

Vaikkakin julkisella arvostuksella, jota mbororot saavat investoidessaan karjaa pyhiinvaellusmatkaan, on paikallista relevanssia, tapa, jolla karjanhoitajat itse ymmärtävät karjan yhteyden pyhiinvaellukseensa, on paljon hienosyisempi. Ensinnäkin yksilön valmius pyhiinvaellukselle ei tarkoita vain hänen kykyään kustantaa matkansa. Riittävän karjamäärän lisäksi pyhiinvaellukselle lähteminen edellyttää aina myös suosiollisella hetkellä tulevaa jumalallista kutsua. Mbororot käyttävät pyhiinvaellukselle lähdöstä puhuessaan sellaisia ilmaisuja kuin "Alla ewni ma" (suom. "Jumala kutsui sinua") tai "Alla wadi geDal ma" (suom. "Jumala valmisti sinulle osasi") (esim. H2; H4; KPM 2). On kuitenkin merkille pantavaa, etteivät mbororot monien muiden muslimien tapaan (ks. esim. Roff 1985, 82) viittaa mihinkään konkreettiseen tapahtumaan, uneen tai muuhun vastaavaan, mikä voitaisiin tulkita tällaiseksi kutsuksi.

Miten sitten pyhiinvaellukselle lähdön ajankohta määräytyy mbororo-kulttuurissa? Otan esimerkin eräästä tuntemastani mbororo-leiristä. Leirin jäsenistä Mekkaan 


\section{Karjanhoitajat MeKassa}

lähti ensin isä vuonna 1988, jonka jälkeen noin 3-4 vuoden päästä pyhiinvaellusvuorossa oli tämän vanhin poika. Vuonna 1997 pyhiinvaellukselle lähti isän ensimmäinen vaimo kolmanneksi vanhimman pojan kanssa, ja vuonna 1999 lähtövuorossa olivat pariskunnan toinen, neljäs ja kuudes poika. Äitiä lukuun ottamatta mainitsemieni leirin jäsenten pyhiinvaellusjärjestys määräytyi pyhiinvaellukselle lähtijän karjamäärän - eikä esimerkiksi syntymäjärjestyksen - mukaan. Poikkeuksen muodosti viides poika, joka ei viimekertaiseen Adamaouan matkaani mennessä (2005) ollut käynyt Mekassa, vaikka hänellä olisi ollut sitä varten tarpeeksi karjaa jo vuosien ajan. Kyseisen pojan pyhiinvaellukselle lähdön esteeksi olivat nousseet häntä kohtaan toistuvasti esitetyt noituussyytökset.

Esimerkki havainnollistaa pyhiinvaelluksen kytkeytymisen sekä lähtijän karjamäärään että tämän moraaliseen statukseen karjanhoitajayhteisössä. Vaikka karjaa tarvitaan, sitä ei voi pitää riittävänä edellytyksenä pyhiinvaellukselle. Pikemminkin se voidaan nähdä merkkinä samasta jumalallisesta siunauksesta (barka), joka tekee myös hijjun mahdolliseksi (6). Mbororojen karjan myynnistä hijjuunsa saama raha täyttääkin oivallisesti ne rehellisesti ja kunniakkaasti ansaitun "hyvän rahan" tunnusmerkit, joita muslimit eri puolilla maailmaa pitävät pyhiinvaellukseen käytetylle varallisuudelle välttämättöminä (Roff 1985, 81).

Julkinen arvostus, jota yksittäinen karjanhoitaja-pyhiinvaeltaja nauttii kylissä, saa pyhiinvaelluksen helposti näyttämään jonkinlaiselta yhden miehen projektilta, jonka myötä karja yksityisenä pääomana muuttaa maallikon kunnioitetuksi Alhajiksi. Vaikka tavallisesti pyhiinvaeltaja maksaa hijjunsa omalla karjallaan, lähemmin tarkasteltuna tilanne paljastuu monimutkaisemmaksi. Ensinnäkin, jos tuleva pyhiinvaeltaja on vanhempi mies, joka on jo jakanut kaiken karjansa poikiensa kesken, hänen pitää pyytää tarvittava karja "takaisin" omilta lapsiltaan. Vastaavalla tavalla vanhempien naispuolisten pyhiinvaeltajien on matkalle lähteäkseen tukeuduttava poikiinsa. Toiseksi tietyn henkilön pyhiinvaellusprojektiin on lähisukulaisten lisäksi usein sekaantunut suuri joukko muita ihmisiä. Minulle kerrotuissa pyhiinvaelluskertomuksissa tämä tulee esiin tavassa nimetä ne ihmiset, jotka ovat jollain tapaa edesauttaneet matkan toteutumista, tavallisesti rahalahjoituksen muodossa. Niissä tapauksissa, joissa lahjoittaja kuuluu itse mbororoihin, lahjoitettu raha on hyvin suurella todennäköisyydellä peräisin karjanhoidosta. Kun lahjoittaja on mies, raha on usein peräisin karjan myynnistä; kun taas lahjoittaja on nainen, raha on yleensä ansaittu maitotuotteiden myynnillä.

\section{KARJANHOIDON VAIHTELEVAT MORAALIT}

Kuvaamani (raha)lahjaverkoston kautta karja yhdistää suuren joukon ihmisiä yhteen pyhiinvaellusprojektiin. Sen lisäksi, että kyseisten lahjojen voidaan nähdä symboloivan karjanhoitajayhteisön sisäisiä sosiaalisia suhteita, ne myös yhdistävät lahjoittajan suoraan Mekkaan. Hijjun aikana rahalahjat, ja sitä kautta näiden lahjojen alkulähde eli karja, muuntuvat jumalalliseksi siunaukseksi, josta lahjoittajat pääsevät osalliseksi pyhiinvaeltajan palatessa kotiin. Sama tapahtuu myös matkaan varta vasten investoidulle 


\section{TEA ViRTANEN}

karjalle. (Ks. kaavio 1.) Jotta tämä prosessi ja sen logiikka tulisi ymmärrettävämmäksi, on syytä taas palata Adamaoualle, karjanhoitoon ja niihin merkityksiin, joita mbororot liittävät omaan karjaansa.

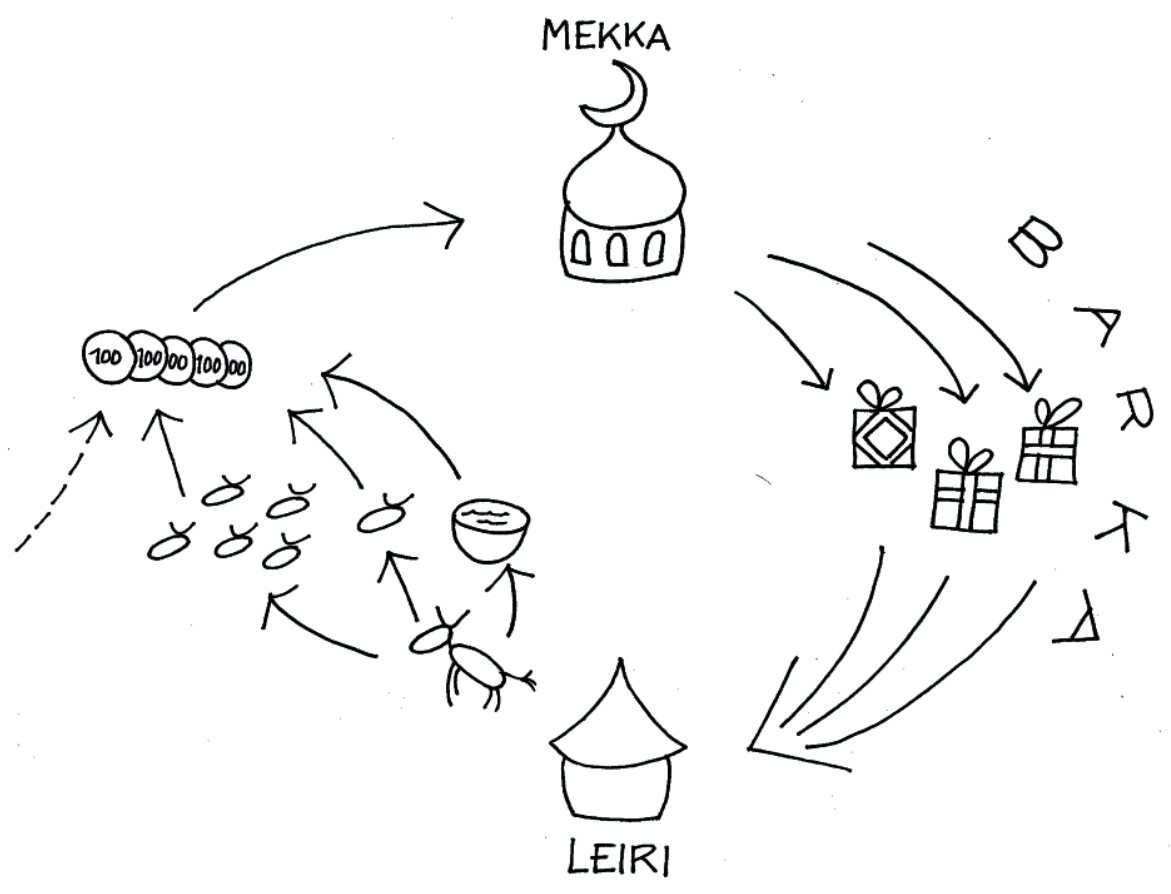

Kaavio 1. Karjan transformoituminen siunaukseksi mbororojen pybïnvaellusprojektin aikana.

Yhtenä kehityssuuntana Kamerunin karja-aitaksi kutsutulla Adamaoualla voidaan nykyään pitää karjanhoidon kaupallistumista, jota ovat vauhdittaneet mbororojen paikalleen asettuminen ja islamisaatio (Boutrais 1978; 1986; Burnham 1996). Tämän kehityksen seurauksina on nähty muun muassa siirtyminen ensisijaisesti maitoa tuottavasta nautakarjasta lihaa tuottavaan karjaan sekä karjanomistussuhteiden muutos kollektiivisesta omistuksesta enemmän yksityisomistusta muistuttavaan suuntaan (Dognin 1975). Kyseisestä suuntauksesta huolimatta karja symboloi mbororoille edelleen vahvasti karjanhoitajayhteisön moraalisia arvoja ja yhtenäisyyttä. Monille muille afrikkalaisille karjanhoitajakulttuureille tyypilliseen tapaan mbororojen käsityksissä karjan ja sitä hoitavan ihmisryhmän välillä on läheinen sosiaalinen ja moraalinen yhteys. Tämä yhteys ilmenee esimerkiksi ideaalissa, jonka mukaan karjan tulisi kiertää tai sitä tulisi kierrättää vain oman, usein linjasukuna ymmärretyn ryhmän sisällä. Oman tutkimukseni kohteena olevien $A k u$-mbororojen (7) kohdalla tämä kulttuurinen ideaali saa erityismuotonsa perinteisessä pienikokoisessa, runsaasti maitoa tuottavassa valkoisessa daneeji seebu-karjassa, joka vertautuu edelleen etenkin kyläläisten suosimaan, erityisesti lihan tuotantoa varten jalostettuun ruskeaan gudaali-karjaan. 


\section{Karjanhoitajat MeKassa}

Mbororojen näkökulmasta daneeji- ja gudaali-karjarotujen välinen ero ei kuitenkaan rajoitu vain tuotannollisiin seikkoihin, vaan se edustaa myös moraalista eroa heidän oman karjanhoitonsa ja kyläläisten karjanhoidon välillä. Puheessa tämä ero ilmaistaan mbororoille keskeisen seuraamisen metaforan kautta. Karjan seuraamisen kielikuva viittaa ajatukseen karjanhoitajayhteisöstä, joka Adamaouan savannilla seuraamastaan karjasta riippuvaisena kykenee samalla säilyttämään jonkinasteisen riippumattomuuden kylissä asuvista paikallisista vallanpitäjistä. Karjan seuraaminen voidaankin ymmärtää toisenlaiseen, kyseenalaisempaan seuraamiseen vihjaavaksi moraaliseksi metaforaksi. Tällaiseen seuraamiseen karjanhoitajat viittaavat esimerkiksi käyttäessään kylissä asuvista muslimeista rahan seuraamisen kielikuvaa.

Kun mainitut kaksi seuraamisen metaforaa - karjan seuraaminen ja rahan seuraaminen - asetetaan vastakkain, ne alkavat edustaa sitä eroa, jonka mbororot tekevät kahden erilaisen "karjanhoitomoraalin" eli karjanhoitoa motivoivan moraalijärjestelmän välille. Soveltaen Jonathan Parryn ja Maurice Blochin (1989) jaottelua, johon palaan tarkemmin artikkelin loppuosassa, on olemassa ensinnäkin karjanhoitajien oma moraalinen maailma, joka perustuu pitkäkestoisiin sosiaalisiin arvoihin. Näitä arvoja ilmentää esimerkiksi maidon ja lihan jakaminen sukulaisten kesken erilaisissa kollektiivisissa rituaaleissa. Toiseksi on olemassa kylän moraali - tai moraalittomuus - joka palvelee lyhytnäköisiä individualistisia päämääriä. Näitä individualistisia pyrkimyksiä vuorostaan ilmentää gudaali-karjan kasvattaminen kaupallisiin tarkoituksiin. On syytä kuitenkin täsmentää, että kuvaamissani seuraamisen metaforissa on pitkälti kysymys tiettyyn kontekstiin sidotusta identiteettiretoriikasta - mbororot ovat toki aina myyneet osan karjaansa rahasta ja tekevät sitä nykyään enenevässä määrin. Lisäksi sama kollektiivisten ja individualististen arvojen välinen dilemma, jota mbororot käyttävät tehdessään eron itsensä ja kyläläisten välille, voidaan ottaa käyttöön myös karjanhoitajien puhuessa oman ryhmänsä sisäisistä hierarkioista.

\section{"ANNOIN POIS KAIKEN"}

Edellä kuvaamani paikalliset seuraamisen metaforat - kuin myös tavat, joilla niitä käytetään tehtäessä kulttuurisia rajanvetoja ihmisten välille - seuraavat mbororoja myös Mekkaan. Samat kielikuvat, joita käytetään kuvattaessa kyläläisten ahneutta, kun nämä kasvattavat karjaa vain rahan vuoksi, toistuvat pyhiinvaelluskertomuksissa silloin, kun aletaan pohtia ihmisten pohjimmaista motivaatiota lähteä pyhiinvaellukselle. Kaikkein selvimmin tämä tulee esiin Mekasta ostettujen tavaroiden moraalisessa arvioinnissa. Siinä missä karjanhoitajat perustelevat omia ostoksiaan Mekasta sosiaalisilla ja uskonnollisilla syillä, kylämuslimien tapauksessa koko kaupanteko näyttäisi mbororojen näkökulmasta perustuvan itsekkääseen ja puhtaasti taloudelliseen motivaatioon. Havainnollistan näkemystäni kolmella haastattelusitaatilla. Ensimmäisessä otteessa puhuu pyhiinvaelluksella käynyt nainen. Toisessa otteessa taas keskustelee kolme miestä, joista vain yksi oli haastatteluhetkellä käynyt Mekassa ja saanut siten Alhajin arvonimen. Kolmannessa otteessa äänessä on pyhiinvaelluksella käynyt mies. 


\section{TEA ViRTANEN}

Ote 1:

Hajja Rekia: Jotkut ihmiset menevät pybiinvaellukselle seuratakseen Jumalaa. Toiset menevät, ostavat tavaroita (kare), tuovat ne mukanaan kotiin ja myyvät (soorra) ne.

TV: Ketkä tekevät niin?

Hajja Rekia: Hausat [= Nigeriasta ja Nigeristä Kameruniin muuttanut etninen ryhmä]. Kun hausat menevät pybiinvaellukselle, he menevät vain ostaakseen tavaroita ja palaavat takaisin. Kun he ovat rukoilleet Medinassa, he rukoilevat Mekassa, byvä, lopun ajasta be eivät tee mitään munta kuin ostavat tavaraa myytäväksi. Ihmisten syy mennä pybiinvaellukselle on tehdä ostoksensa loppuun ja palata takaisin. He ostavat, he kokoavat myytäväksi tarkoitetut tavarat. Heitä näkee paljon. Ei ole mitään, mikë heitä huolettaisi.

TV: Koska Mekassa on paljon tavaroita.

Hajja Rekia: Koska tavaroita on paljon, tavaroita on liian paljon. Kankaita [...] [erilaatuisia kankaita], viidellä boorolla [= 1,52 euroa]. Ne eivät maksa enempää, saat kaikki viidellä boorolla. Kuten näillä lapsilla (osoittaa vieressä leikkivien lasten vaatetusta), yhdellä rialilla, kahdella rialilla, kaikkea he ostavat juuri niin ja keräävät tavaransa ybteen. (H2)

Ote 2:

Alhaji Nayeeri: Me ostamme [uskonnollisia] kirjoja, annamme ubrilabjoina (sakka), labjoitamme kirjoja ubrilahjoina (sadaka), annamme ubrilabjoina isille ja äideille. Sitten ostamme sieltä vaatteita, [joita] tuomme lapsille.

Umaru: Palaamme [Mekasta] vesileilejä ja munta [tavaraa] mukanamme, annamme [niitä] kaikille ibmisille.

Alhaji Nayeeri: Ibmiset tulevat saadakseen siunauksen (barkitaaki).

Saibu: Täällä meillä ei käydä kauppaa (coggu).

Umaru: Ei ole kauppaa! Millään niistä tavaroista, joita tuomme Mekasta, emme käy kauppaa.

Saibu: Jokainen [joka tulee tervehtimään sinua palattuasi pyhiinvaellukselta] saa siunauksen (barkiti). Annat.

Umaru: Kunnes olet antanut kaiken!

Alhaji Nayeeri: [Annat ] kunnes olet antanut pois kaiken. [Se on] ubrilabja [jonka] annat. [...] Kaikkijotka tulevat [tervehtimään sinua], jos heidän osansa (geDal) on saapunut, annat [sen heille]. [...] Ei ole mitään, mitä et antaisi pois. (H1)

Ote 3:

Alhaji Abdu: He menevät. [...] Hausat, baafumilaiset, maronalaiset [= Kamerunin eri osissa asuvaa väestöä], kylissä asuvat ihmiset, he menevät vain ostamaan tavaroita Arfasta. He tulevat takaisin, he eivät tee mitään munta kuin myyvät tavaroita kalliista binnasta. [...] Minä labjoitin (saabi) kaiken. Ostin mattoja, niitä pieniä, joiden päällä rukoillaan, yhden, toisen, ybteensä kymmenen mattoa. [...] En jättänyt [niistä] itselleni ainuttakaan. Annoin kaikki pois ubrilabjoina. Kaikki tulivat [luokseni]. [...] Nïn, meidän keskundessamme kaupankä̈ntiä ei ole. Jos menet [Mekkaan], et käy kauppaa. Jotkut kuulivat untisen [paluustani], 


\section{Karjanhoitajat MeKassa}

jotkut tulivat Baafumista asti, ihmiset, jotke tunsivat minut. Joku, jolla on varaa vain pulloon öljyä, tulee, [...] tunnistan bänet, annan. Tässä on osasi, jonka löydät. Tässä on joku, joka saa vaatteen, joku, joka saa rukousnauban, joku, joka saa kaksi olkapäille laitettavaa [pybiinvaellusasuksi tarkoitettua] kankaanpalaa. [...] [Annoin] kunnes kaikkei oli loppu.

TV: Kun tulit takaisin Mekasta, tulivatko ibmiset, kokoontuivat [luoksesi]?

Alhaji Abdu: Kyllä, ibmiset tulivat, kokoontuivat. Minä ubrasin (birsi) bärän. [...] Heitä tuli paljon luokseni, he saivat siunauksen. He tulivat, vanhoja miebiä yli kymmenen, otin kiinni härän, ubrasin sen. [...]

TV: Ja myös Mekassa uhrasit lampaan?

Alhaji Abdu: Kyllä, uhrasin lampaan, suoritin hadyan [= muslimien pyhiinvaelluksen päättävä suuri uhrijuhla Eid-al-Adha], Mekassa kutsuvat sitä hadyaksi. Ubrijublaa, sitä he kutswvat hadyaksi. Minä uhrasin lampaan, ison pässin. (H3)

\section{Karja, MekKa ja siunaus}

Victor Turner $(1974,187,221)$ on pannut merkille pyhiinvaelluksen ja kaupankäynnin välisen yhteyden. Mbororojen puheissa tämä yhteys tulee esiin heidän kertoessaan Mekasta ostettavista tavaroista. Alan Moriniksen $(1992,6)$ mukaan sukulaisille ja tuttaville jaettavat matkamuistot luovat jälkiä pyhiinvaelluskohteista ja symboloivat näihin kohteisiin sisältyviä ihanteita. Länsi-Afrikassa on myös tavallista, että kaupanteko jatkuu hijjun jälkeen pyhiinvaeltajien myydessä Mekasta ostamiaan tavaroita edelleen kotiseudullaan. Yksi tällaista liiketoimintaa harjoittava ryhmä on mbororo-informanttieni mainitsemat hausat, joiden tapaan hyödyntää pyhiinvaellusmatkojaan kaupallisessa mielessä on viitattu useissa tutkimuksissa (ks. esim. Azarya 1978; Bocquené 1986; O’Brien 1999). Kamerunissa osa jo Mekassa käyneistä kauppiaista rahoittaa lisäksi varattomampien muslimien pyhiinvaelluksia sillä edellytyksellä, että nämä ostavat heille Mekasta tavaraa jälleenmyytäväksi.

Otan seuraavaksi lähempään tarkasteluun edellä siteeraamassani keskustelussa eri muodoissaan käytetyt fulfuldenkieliset termit. Kuten tarkastelusta käy ilmi, kyse on sellaisista termeistä, joiden avulla mbororot tekevät laadullisen eron pyhiinvaellukseen yhdistettyjen vaihdon eri muotojen ja niihin liittyvien Mekasta mukana tuotujen tavaroiden välille.

Termit soorrugo (suom. 'myydä'), kare (suom. ' kauppatavara') ja coggu (suom. 'kaupankäynti') kuuluvat markkinavaihdon eli hyödykkeiden vaihdon alueelle, ja keskusteluissa niillä luonnehditaan erityisesti kylissä asuvien muslimien toimintaa. Karjanhoitajien puheissa kyläläiset näyttäytyvätkin ihmisinä, jotka jopa Mekassa seuraavat vain rahaa ja siten heidän toimiaan motivoi taloudellisen hyödyn tavoittelu. On kuitenkin syytä korostaa, että karjanhoitajat näyttäisivät itse ostavan Mekasta melko samantyyppisiä tavaroita - vaatteita, uskonnollista kirjallisuutta, rukousnauhoja ja rukousmattoja - kuin kylien muslimit, joskin viimeksi mainitut ostavatkin mbororoja useammin esimerkiksi elektroniikkaa (Bocquené 1986, 302-303). Tyypillistä onkin 


\section{TEA ViRTANEN}

se, että mbororojen näkökulmasta ero oman ja kyläläisten hijjun välillä ei johdu heidän Mekasta ostamiensa tavaroiden laadusta tai määrästä sinänsä. Sen sijaan ero liittyy siihen, millaisiin transaktioihin kyseiset tavarat siirtyvät ostohetkensä jälkeen. Karjanhoitajien ajattelutavan mukaan Mekasta ostetuista tavaroista tulee kyläläisten käsittelyssä hyödykkeitä. Mutta kulkiessaan karjanhoitajien käsien kautta samanlaiset Mekasta ostetut tavarat käyvät läpi hyvin erilaisen transformaation. Haastatteluotteissa tätä transformaatiota kuvaavat sellaiset termit kuin sadaka (suom. 'uhrilahja', 'almu'), sakkugo ('antaa uhrilahja'), birsugo ('teurastaa', 'uhrata'), kirsol ('karjauhri'), saahaago ('lahjoittaa'), barka ('siunaus') ja geDal ('osa', 'osuus'). Näitä termejä informanttini käyttävät, kun he kuvaavat omaa pyhiinvaellustaan ja sille tyypillistä toimintaa.

Termeistä ensimmäinen, sadaka, kuten myös siitä johdettu verbimuoto sakka, lainautuu arabian kielestä ja tarkoittaa 'uhrilahjaa' tai 'almua' eli toisin sanoen lahjaa, jonka antamisella on uskonnollinen motiivi ja joka liittyy muslimien uskonnolliseen velvollisuuteen lahjoittaa almuja. Esimerkiksi pyhiinvaelluskauden päättävässä uhrijuhlassa tätä velvollisuutta tulisi noudattaa jakamalla osa uhratusta eläimestä köyhille. Kun mbororot uhraavat nautoja tai lampaita erilaisissa rituaalisissa tilanteissa, heillä on kuitenkin tapana jakaa teurastetun eläimen liha kokonaisuudessaan omista sukulaisistaan ja naapureistaan koostuvien läsnäolijoiden kesken, olivatpa nämä sitten rikkaita tai köyhiä. Tämä käytäntö koskee yhtä lailla islamilaiseen vuodenkiertoon liittyviä juhlia kuin karjanhoitajien omia, yksilön elämänkaaren käännekohdissa järjestettäviä siirtymärituaaleja. Siten myös sellaiset eläinuhrit, jotka islamin näkökulmasta on tulkittavissa almujen annoksi, vertautuvat mbororojen suorittamina näiden suuresti arvostamaan traditionaaliseen karjauhriin (kirsol, verbistä birsugo) ja siitä saatavan lihan jakamiseen leirissä. Sillä taas on keskeinen rooli esimerkiksi useassa avioliiton solmimiseen ja uuden kotitalouden perustamiseen liittyvässä rituaalissa. (8) Toisaalta on myös mielenkiintoista havaita, miten sadaka-termiä nykyään käytetään esimerkiksi kirsol-uhrista, jonka mbororot toisinaan suorittavat leirissään vierailevan sukulaisen kunniaksi. Käytännössä onkin usein hyvin vaikea erottaa erilaisissa tilanteissa suoritettavien karjauhrien uskonnollisia ja karjanhoitajien omiin traditioihin liittyviä motiiveja toisistaan. (9)

Analyyttisen kehyksen kirsol-instituution merkityksen pohdinnalle, kuin myös tämän artikkelin laajemmalle pyhiinvaelluskeskustelulle, tarjoavat Jonathan Parry ja Maurice Bloch (1989, 23-28). Heidän mukaansa erilaisissa yhteiskunnissa voidaan erottaa kaksi toisistaan poikkeavaa ja ihmisten toimintaa jäsentävää vaihtosykliä eli transaktionaalista järjestystä (engl. transactional orders). Näistä ensimmäisellä he viittaavat lyhyellä aikavälillä tapahtuvaan, yksilön omistushaluun perustuvaan vaihtoon, kun taas toisessa vaihtosykleistä tähdätään heidän mukaansa pitkän aikavälin sosiaalisen ja kosmisen järjestyksen uusintamiseen yhteiskunnassa. Keskeistä Parryn ja Blochin jaottelussa on se, että he eivät näe näitä vaihtosyklejä toisiaan pois sulkevina vaan pikemminkin toisistaan riippuvaisina ja toisiaan täydentävinä rinnakkaisina prosesseina. Tähän riippuvuuteen sisältyy kuitenkin hierarkkinen ulottuvuus, sillä yksilön lyhytaikaiset intressit ovat Parryn ja Blochin näkemyksen mukaan viime kädessä alisteisia pitkäaikaisen sosiaalis-kosmisen järjestyksen uusintamiselle. Kaikissa yhteiskunnissa on ainakin jossain määrin oikeutettua tai jopa suositeltavaa se, että yksilö ajaa omia 


\section{Karjanhoitajat MeKassa}

lyhytaikaisia intressejään. Tämän individualististen toiminnan lopullinen arvo määrittyy kuitenkin sen mukaan, missä määrin sen tuotto on valjastettavissa palvelemaan laajemman syklin ylläpitoa.

Monen muun afrikkalaisen karjanhoitajayhteiskunnan tapaan mbororojen karjalla ja siihen liittyvillä transaktioilla on tärkeä rooli ylläpidettäessä kyseisen yhteiskunnan pitkäaikaista sosiaalista järjestystä. Yksi tähän järjestykseen liittyvä ideaali on karjan pitäminen karjanhoitajayhteisön sisällä, toisin sanoen karjanhoitajien keskinäisen vaihdon välineenä, jonka noudattamisessa rituaalien alueella kirsol-uhrilla on keskeinen merkitys. Fulfulden kielessä tätä karjaan liittyvää, yhteisön sosiaalismoraalisten rajojen sisällä pysymisen ideaalia ilmaisee sanonta "na'i wurtataa yaasi" (suom. "lehmät eivät mene ulkopuolelle"). Mutta miten tämä kaikki liittyy Mekkaan? Yhteys on löydettävissä edellä esitetystä haastattelusitaatista, jossa Alhaji Abdu kertoo suorittamistaan kahdesta eläinuhrista: lammasuhrista Mekassa ja härkäuhrista kotileirissä pyhiinvaelluksen päätyttyä. Näiden toisiaan seuraavien eläinuhrien voidaankin ymmärtää nivovan kaksi sosiaalis-kosmista maailmaa, Mekan ja karjanhoitajayhteisön, toisiinsa samaan moraalisen vaihdon kokonaisuuteen. Myös edellä luettelemistani termeistä lahjoittamista tarkoittava saahaago viittaa tälle samalle moraalisten transaktioiden alueelle. Yhdessä uhriin ja uhraamiseen viittaavien termien kanssa se muodostaa vastakohdan kaupankäynnille ( $\operatorname{cogg} u)$. Karjan kohdalla yhtenä esimerkkinä tästä vastakkainasettelusta voidaan mainita karjanhoitajayhteisön sisäisten karjalahjojen ja karjamarkkinoilla tapahtuvan karjan myynnin välinen ero.

Karjanhoitajayhteisön ja Mekan välisten kytkentöjen ymmärtämisessä keskeisen sijan saa myös siunausta tarkoittava barka-termi. Kukaan ei lähde pyhiinvaellukselle ilman jumalallista siunausta, ja kuten haastattelusitaatissakin tuli esiin, sama siunaus odottaa ihmisiä, jotka tulevat tervehtimään kotiin palannutta pyhiinvaeltajaa. Käsitys Mekasta kotiin palavien pyhiinvaeltajien mukana "leviävästä" voimallisesta siunauksesta ei toki ole syntynyt mbororo-leireissä, vaan sen jakavat muslimit ympäri maailmaa (Roff 1985, 82). On kuitenkin syytä tähdentää, että karjanhoitajien keskuudessa barka ei ole ymmärrettävissä pelkästään jonkinlaiseksi henkiseksi substanssiksi vaan voimaksi, joka saa myös konkreettisen muodon. Eli jos jonkun henkilön sanotaan omaavan barka-siunausta, se usein tarkoittaa, että hänellä on erilaisten sosiaalisten hyveiden, kuten anteliaisuuden ja oikeudenmukaisuuden, lisäksi paljon jälkeläisiä, karjaa tai muuta vaurautta. (10) Karjan kohdalla barkan vaikutus näkyy erityisesti aiemmin mainitsemassani perinteisessä daneeji-karjassa, jolla ymmärretään olevan paljon siunausta, osittain sen nopean lisääntymiskyvyn vuoksi. Tässä kohtaa voidaankin nähdä mielenkiintoinen yhtäläisyys. Toisaalta barka tuottaa vaurautta karjanhoitajaleireissä kasvavan karjamäärän ja uusien linjasuvun jäsenten eli uusien jälkeläisten muodossa. (11) Toisaalta Mekka mielletään paikaksi, jossa kaikki se, mitä pyhiinvaeltajalla on sinne lähtiessään, moninkertaistuu. (12) Siten se karja, joka on investoitu pyhiinvaellusmatkaan, käy läpi erityisen transformaation (ks. kaavio 1): ensin se poistuu karjanhoitajayhteisöstä samalla tapaa kuin markkinoilla myytävä karja - mutta vain palatakseen Mekan kautta takaisin moninkertaistuneena siunauksena. Tämä siunaus materialisoituu Mekasta ostetuissa lahjoissa. 


\section{TEA ViRTANEN}

Koko pyhiinvaellusprosessi voidaan tiivistää fulfulden kielen termiin geDal, joka tarkoittaa 'osaa' tai 'osuutta' ja jota karjanhoitajat käyttävät erilaisissa yhteyksissä. Sillä voidaan viitata esimerkiksi elämään osana, jonka Jumala on antanut ihmiselle, tai keskinäiseen ymmärrykseen, joka pitää aviopuolisot yhdessä. Pyhiinvaelluksen yhteydessä ilmaisuja "geDal wari" (suom. "[jonkun] osa on saapunut") ja "Alla wadi geDal" (suom. "Jumala valmisti [jollekin] osan") (esim. H2; KPM2) käytetään esimerkiksi silloin, kun tietty henkilö on lähtemässä Mekkaan ja hänen oletetaan siten saaneen jumalallisen kutsun pyhiinvaellukselle. Yleisemmällä tasolla voitaisiin ajatella, että termi geDal sisältää ajatuksen osasta tai osuudesta, jota ihminen ei saa omien yksilöllisten pyrkimystensä tai saavutustensa tuloksena vaan siksi, että hän moraalisessa mielessä kuuluu johonkin laajempaan sosiaaliseen kokonaisuuteen. Voidaankin esittää, että koska erityisesti karja symboloi mbororo-yhteisön pitkäkestoista moraalista järjestystä, niin siinä ruumiillistuu geDal-termin perusidea tai ydin. Tämä karjan ja geDalin välinen yhteys saa näkyvän muodon erilaisissa rituaaleissa suoritettavassa kirsol-uhrissa, kun karjanhoitajat käyttävät kyseistä termiä viitatessaan siihen osaan, jonka he saavat uhratusta eläimestä. Pyhiinvaelluksen yhteydessä geDal-termin sosiaalis-moraalinen ulottuvuus kulminoituu pyhiinvaeltajan paluussa, kun kaikille paikalle saapuville kuuluu osa hijjun päätteeksi uhrattavasta härästä. Mutta vähintään yhtä merkittävästä karjan tuottamasta moraalisesta osuudesta ja siunauksesta on kyse Mekasta tuoduissa lahjoissa. Sen jälkeen, kun osa pyhiinvaellukseen investoidusta karjasta on muunnettu Mekassa lahjoiksi, samaa geDal-termiä käytetäänkin siitä osasta, jonka pyhiinvaeltajaa tervehtimään tullut henkilö saa näistä lahjoista uuden Alhajin tai Hajjan palatessa kotiin.

\section{LOPUKSI}

Pyhiinvaelluksesta käydyissä teoreettisissa pohdinnoissa on usein keskitytty kuvaamaan toisaalta pyhiinvaeltajien matkaa kotoa pyhiinvaelluskohteeseen ja takaisin, toisaalta itse pyhiinvaelluskohteen sakraalia topografiaa pyhine paikkoineen ja objekteineen. Keskustelua ovat herättäneet etenkin Turnerin kiistellyt näkemykset pyhiinvaelluksesta siirtymäriittinä sekä pyhiinvaeltajien keskenään jakamasta statuksettomasta communitas-tilasta. Hedelmällisempää kuin korvata yhden tutkijan teoriat uusilla universalismeilla on kuitenkin uskaltaa luottaa omaan tutkimusaineistoonsa. Yamban $(1990,9)$ sanoin: "Parasta, mitä kukaan pyhiinvaellustutkimusta aloitteleva voi tehdä, on toivoa, että oman etnografian erityislaatu tulee apuun.” Tärkeämpää kuin kiistellä erilaisten teorioiden universaalista paremmuudesta tai sovittaa oma tutkimus valmiisiin analyyttisiin malleihin onkin, mbororojen metaforaa lainatakseni, "seurata" omaa tutkimusaineistoaan. Samalla aukeaa myös pyhiinvaellukselle annettuja, paikallisesti määräytyneitä merkityksiä, jotka pelkkään pyhiinvaelluksen suorittamiseen keskittymällä jäävät helposti huomaamatta.

Olen tässä artikkelissa tuonut esiin merkityksiä, joiden kautta Kamerunin Adamaoualla asuvat mbororo-karjanhoitajat hahmottavat ja tulkitsevat sekä omia että 


\section{Karjanhoitajat MeKassa}

toistensa pyhiinvaelluskokemuksia. Nämä merkitykset ja niihin liittyvät symbolit ja kielikuvat kumpuavat karjahoitajien tutuista jokapäiväisistä kokemuksista, joka selittää niiden voimaa myös pyhiinvaelluksen kontekstissa. Mbororojen kertoessa hijjusta Mekkaan heidän puheessaan ei korostunut kulttuurien rajat ylittävä muslimipyhiinvaeltajien välinen yhteenkuuluvuuden tunne. Lähemmäksi ajatusta communitas-tilasta tulivat mbororojen kertomuksissa heidän kuvauksensa toisaalta kaukana, useimmiten Nigeriassa, asuvien sukulaisten tapaamisesta Mekassa, toisaalta oman leirin jäsenten ja naapurien iloisesta jälleennäkemisestä pyhiinvaellukselta palatessa.

Mitä taas tulee mbororojen suhteeseen Adamaouan alueen muihin, kylissä asuviin muslimipyhiinvaeltajiin, yhteenkuuluvuuden tunteen sijasta karjanhoitajien kerronnassa korostui voimakkaasti heidän oman pyhiinvaelluksensa moraalinen ja sosiaalinen erityisyys verrattuna kyläläisten Mekan matkoihin. Tämän erityisyyden rakentumisessa tärkeässä roolissa on karja, joka omalla metaforisella pyhiinvaelluksellaan (Morinis 1992, 4) seuraa mbororoja Mekkaan ja takaisin. Karjan keskeinen merkitys mbororojen pyhiinvaelluksessa perustuu siihen, että pyhiinvaellusprosessin aikana se ei koskaan ylitä karjanhoitajien moraalisen maailman rajoja vaan pikemminkin korostaa ja vahvistaa niitä. Edellä kuvaamani transformaation kautta karjasta tulee keskeinen symboli, jonka välityksellä pyhiinvaellus nivotaan osaksi karjanhoitajayhteisön sosiaalis-kosmista järjestystä. Samalla tämän järjestyksen moraalista arvoa lisäävät juuri ne mbororot, jotka vuosittain pyhiinvaellukselle lähtemällä ja sieltä palaamalla luovat yhteyden oman leirinsä, koko karjanhoitajayhteisön ja Mekan pyhän kaupungin välille.

\section{VIITTEET}

1. Artikkeli perustuu Suomen Kansantietouden Tutkijain Seurassa maaliskuussa vuonna 2005 pitämääni vuosikokousesitelmään.

2. Tein osallistuvaan havainnointiin ja haastatteluihin pohjaavaa antropologista kenttätyötä Kamerunin Adamaoualla vuosina 1995-1996 ja 1998 yhteensä noin 15 kuukauden ajan. Sen jälkeen olen tehnyt lyhyempiä matkoja alueelle vuosina 2004 ja 2005. Kenttätyöni aikana keskeiseksi tutkimuskysymykseksi muodostui islamisoitumisen ja osittaisen paikalleen asettumisen vaikutus mbororojen kulttuuriin; väitöskirjassani (Virtanen 2003) tarkastelin aihetta performatiivisuuden näkökulmasta.

3. Yksilön kokemusta korostavaa näkemystä myötäilee myös René Gothóni (1993; 2000) Athoksen Pyhän vuoren luostareiden pyhiinvaellusta koskevissa tutkimuksissaan (ks. myös Kilpeläinen 2000, 360-362).

4. Tässä artikkelissa käytän pyhiinvaelluksesta fulfuldenkielistä termiä hijju sekä mies- ja naispuolisista pyhiinvaeltajista arvonimiä Alhaji ja Hajja. Fulfulden kielen kirjoitusasussa seuraan Noyea (1989). Kiitän Abdoullahi Babaa hänen avustaan joidenkin haastatteluaineistooni sisältyvien fulfuldenkielisten termien ymmärtämisessä ja kääntämisessä. 


\section{TEA ViRTANEN}

5. Puhuessaan 'puskan ihmisistä' (himBe ladde) ja 'kylän ihmisistä' (himBe wuro) mbororot viittaavat yleensä eroon itsensä ja kylä-fulbeista sekä muista kylien asukkaista - esimerkiksi mbumeista, vuteista ja nigerialaisperäisistä hausoista - koostuvan muslimiväestön välillä. Dikotomia on yksinkertaistava, sillä Adamaouan kylissä asuu myös kristittyjä ja savannilla mbororojen lisäksi etenkin maanviljelyä harjoittavia gbayoja.

6. Mbororojen islamisaatioon liittyvä käsitys karjan jumalallisesta alkuperästä on nähtävissä myös Adamaoualla keräämissäni mbororojen alkuperämyyttien uusissa versioissa. Niissä mbororot saavat karjansa varhaisimmissa myyteissä esiintyvän, mbororojen kantaisänä pidetyn veden hengen sijasta profeetta Muhammedilta. (Virtanen 2003, 91-95.)

7. Kamerunin mbororojen kaksi pääryhmää, Jaafun- ja Aku-karjanhoitajat, ovat molemmat osa samaa, 1800-luvun lopulla Nigeriasta alkanutta vaellushistoriaa, jonka myötä suurin osa Kamerunin mbororo-väestöstä on saapunut maahan (ks. Dognin 1981). Kyseisten, Kameruniin saapumisen myötä toisistaan eriytyneiden ryhmien välillä on hierarkkinen suhde, joka perustuu niiden saapumisjärjestykseen. Ylempänä hierarkiassa ovat ensin saapuneet Jaafunit, jotka ovat Kamerunissa kyläfulbejen vaikutuksesta omaksuneet paikallaan pysyvämmän ja Islamia tiukemmin noudattavan elämäntyylin kuin myöhemmin saapuneet, nomadisemmat ja omia karjanhoitoon liittyviä perinteitään uskollisemmin vaalivat Akut.

8. Tietyissä tilanteissa islamilainen ja "traditionaalinen" eläinuhri voidaan myös konkreettisesti erottaa toisistaan. Esimerkiksi indeeri-rituaalissa, jossa viikon ikäiselle lapselle annetaan nimi, mbororot suorittavat, varallisuuden niin salliessa, kaksi peräkkäistä eläinuhria: varhain aamulla islamilaisen lammasuhrin ja myöhemmin, varsinaisen nimenannon jälkeen, perinteisen härkäuhrin (Virtanen 2003, 160-161).

9. Samanlaisia huomioita on esitetty myös muun tyyppisten almujen annosta. Esimerkiksi Mirjam de Bruijnin ja Han van Dijkin (1995, 418-420) mukaan Keski-Malin fulbet ovat taipuvaisia lahjoittamaan viljaa mieluummin omille sukulaisilleen ja fulbe-naapureilleen kuin luovuttamaan ylijäämätuotantonsa paikalliselle islamilaiselle johtajalle, joka jakaisi sen almuina edelleen köyhille.

10. Dognin $(1975,298-299)$ tekee semanttisen eron mbororo-fulbejen barkan ja sen arabiankielisen kantasanan, barakan, välille. Siinä, missä arabien baraka viittaa jumalallista alkuperää olevaan voimaan tai siunaukseen, mbororo-fulbejen barka on paremmin ymmärrettävissä vaikutusvaltaisen henkilön jälkeläisilleen siirtämänä voimana, jonka tämä itsekin on perinyt ja joka ilmenee jälkeläisinä, karjana (naisen kohdalla myös lehmien runsaana maitona) sekä elämänkokemuksena. Mbororojen perinteisissä käsityksissä barka liitetäänkin linjasukuun, ja sen väheneminen tai häviäminen pyritään estämään linjasuvun sisäisillä avioliitoilla sekä karjan pitämisellä sukuryhmän sisällä. Islamisoitumisen myötä nämä kaksi käsitystä ovat kuitenkin sekoittuneet toisiinsa, mikä tulee hyvin esiin myös Adamaouan mbororojen pyhiinvaelluskertomuksissa. Islamin vaikutuksesta fulbejen barka-termiin katso myös de Bruijn ja van Dijk $(1995,175)$.

11. Erilaisia vaurauden muotoja, kuten myös sosiaalista menestystään ja viehätysvoimaansa, mbororot pyrkivät lisäämään käyttämällä rituaaleissaan siunausta tuovan, 


\section{Karjanhoitajat MEKASSA}

barka-termin mukaan nimetyn barkeehi-puun (Bauchinia reticulata) lehviä. Esimerkiksi nimenantorituaalissa lehviä heitetään lapsen ajeltujen hiusten kanssa maitoon, ja avioitumisprosessin alkavassa koggal-rituaalissa tulevalle morsiamelle rakennetaan barkeehi-puun oksista symbolinen maja. Barkeehi-lehviä voidaan käyttää myös apuvälineenä ennustamisessa ja niitä poltetaan karja-aitauksen nuotiossa karjan hedelmällisyyden lisäämiseksi.

12. Tämä moninkertaistuminen koskee sekä pyhiinvaeltajan fyysistä omaisuutta että hänen sosiaalisia ominaisuuksiaan. Viimeksi mainittuun viitaten mbororo-informanttini korostivat, että kenenkään ei pidä lähteä Mekkaan pahoja tekoja sydämellään, nämä teot kun estäisivät Mekan siunauksellisen vaikutuksen ja tekisivät pyhiinvaeltajasta vain entistä pahemman ihmisen.

\section{LÄHTEET}

\section{Tutkimusaineistot}

Haastattelut $(\mathrm{H})$ :

— Haastattelu 1: kolme noin 63-71 -vuotiasta miestä. 13.2.1996, Djerem, Kamerun.

— Haastattelu 2: nainen, noin 67 vuotta. 8.6.1998, Djerem, Kamerun.

- Haastattelu 3: mies, noin 72 vuotta. 8.6.1998, Djerem, Kamerun.

— Haastattelu 4: neljä noin 40-73-vuotiasta miestä. 20.6.1998, Djerem, Kamerun.

Kaikkien haastattelujen tekijänä kirjoittaja; haastattelunauhat sekä litteroidut haastattelut tekijän hallussa.

Kenttäpäiväkirjamerkinnät (KPM):

— Kenttäpäiväkirjamerkintä 1: nainen, noin 67 vuotta. 25.5.1998, Djerem, Kamerun.

— Kenttäpäiväkirjamerkintä 2: nainen, noin 67 vuotta. 27.5.1998, Djerem, Kamerun.

Kenttäpäiväkirjat kirjoittajan hallussa.

\section{Kirjallisuus}

AZARYA, VICTOR 1978: Aristocrats Facing Change. The Fulbe in Guinea, Nigeria, and Cameroon. Chicago: University of Chicago Press.

BOCQUENÉ, HENRI 1986: Moi un Mbororo. Ndoudi Oumarou, Peul nomade du Cameroun. Paris: Editions Karthala.

BOUTRAIS, JEAN 1978: Deux etudes sur l'evage en zone tropicale humide (Cameroun). Paris: Editions de l'ORSTOM. 


\section{TEA ViRTANEN}

- 1986: L'expansion des éleveurs peul dans les savanes humides du Cameroun. - Mahdi, Adamu \& Kirk-Greene, A. H. M. (eds.), Pastoralists of the West African Savanna. Manchester: Manchester University Press.

BRUIJN, MIRJAM DE \& DIJK, HAN VAN 1995: Arid Ways. Cultural Understanding of Insecurity in Fulbe Society, Central Mali. Amsterdam: Thela Publishers.

BURNHAM, PHILIP 1996: The Politics of Cultural Difference in Northern Cameroon. Washington D.C.: Smithsonian Institution Press.

DOGNIN, RÉNÉ 1975: Sur trois ressorts du comportement peul. - Monod, Théodore (ed.), Pastoralism in Tropical Africa. London: Oxford University Press: International African Institute.

- 1981: L'installation des Djafoun dans l'Adamaoua camerounais. / La djakka chez les Peul de l'Adamaoua. - Tardits, C. (ed.), Contribution de la recherche ethnologique a l'histoire des civilisations du Cameroun. Paris: Centre National de la Recherche Scientifique.

FERME, MARIANE 1994: What 'Alhaji Airplane' Saw in Mecca, and What Happened When He Came Home. Ritual Transformation in a Mende Community (Sierra Leone). - Steward, Charles \& Shaw, Rosalind (eds.), Syncretism / Anti-Syncretism. The Politics of Religious Change. London: Routledge.

FRANTZ, CHARLES 1978: Ecology and Social Organization Among Nigerian Fulbe (Fulani). - Weissler, Wolfgang (ed.), The Nomadic Alternative. The Hague: Mouton.

Van GENNEP, ARNOLD 1960: The Rites of Passage. Chicago: Chicago University Press. [1909]

GOTHÓNI, RENÉ 1993: Pilgrimage = Transformation Journey. - Ahlbäck, Tore (ed.), The Problem of Ritual. Stockholm: Scripta Instituti Donneriani Aboensis.

- 2000: Uskontojen uustulkintaa. Helsinki: Yliopistopaino.

HICKEY, JOSEPH \& STAATS, GREGORY \& McGAW, DOUGLAS 1979: Factors Associated with the Mecca Pilgrimage among the Bokkos Fulani. - Journal of Asian and African Studies 14(3-4): 217-230.

KILPELÄINEN, HANNU 2000: Valamo-karjalaisten luostari? Luostarin ja ybteiskunnan interaktio maailmansotien välisenä aikana. Suomalaisen Kirjallisuuden Seuran Toimituksia 799. Helsinki: Suomalaisen Kirjallisuuden Seura.

METCALF, BARBARA 1990: The Pilgrimage Remembered. South Asian Accounts of the Haij. - Eickelman, Dale \& Piscatori James (eds.), Muslim Travellers. Pilgrimage, Migration, and the Religious Imagination. London: Routledge.

MORINIS, ALAN 1992: Introduction. The Territory of the Anthropology of Pilgrimage. - Morinis, Alan (ed.), Sacred Journeys. The Anthropology of Pilgrimage. Westport: Greenwood Press.

NOYE, DOMINIQUE 1989: Dictionnaire Foulfouldé- Français. Dialect Peul du Diamaré Nord-Cameroun. Paris: Libraire Orientaliste Paul Geuthner.

O'BRIEN, SUSAN 1999: Pilgrimage, Power, and Identity. The Role of the Hajj in the Lives of Nigerian Hausa Bori Adepts. - Africa Today 46(3): 11-40.

PARRY, JONATHAN \& BLOCH, MAURICE 1989: Introduction. Money and the Morality of Exchange. - Parry, Jonathan \& Bloch, Maurice (eds.), Money and the Morality of Exchange. Cambridge: Cambridge University Press.

ROFF, WILLIAM 1985: Pilgrimage and the History of Religions. Theoretical Ap- 
proaches to the Hajj. - Martin, Richard (ed.), Approaches to Islam in Religious Studies. Tucson: University of Arizona Press.

SALLNOW, MICHAEL 1981: Communitas Reconsidered. The Sociology of Andean Pilgrimage. - Man (n.s.) 16(2): 163-182.

TURNER, VICTOR 1974: Dramas, Fields, and Metaphors. Symbolic Action in Human Society. Ithaca: Cornell University Press.

VIRTANEN, TEA 2003: Performance and Performativity in Pastoral Fulbe Culture. Ph.D. dissertation. Research Series in Anthropology 4. Helsinki: University of Helsinki.

YAMBA, CHRISTIAN BAWA 1990: Permanent Pilgrims. An Anthropological Study of the Role of Pilgrimage in the Lives of West African Muslims in Sudan. Stockholm: University of Stockholm.

Filosofian tohtori Tea Virtanen on tehnyt etnografista tutkimusta Kamerunin mbororo-yhteisöissä Adamaouan alueella ja Yaoundessa. Hän on toiminut tutkijana Helsingin yliopiston sosiaali- ja kulttuuriantropologian laitoksella sekä kulttuuriantropologian lehtorina Joensuun yliopistossa. 